\title{
INTERNATIONAL JOURNAL OF OCCUPATIONAL MEDICINE AND ENVIRONMENTAL HEALTH IN WORLD DOCUMENTATION SERVICES: THE SCOPUS BASED ANALYSIS OF CITATION
} JOLANTA PRZYŁUSKA

Scientific Library

Nofer Institute of Occupational Medicine

Łódź, Poland

\begin{abstract}
A high classification of scientific journals in the ranking of international transfer of knowledge is reflected by other researchers' citations. The International Journal of Occupational Medicine and Environmental Health (IJOMEH) is an international professional quarterly focused on such areas as occupational medicine, toxicology and environmental health edited in Poland. IJOMEH, published in English, is indexed in numerous world information services (MEDLINE, EMBASE, EBSCO, SCOPUS). This paper presents the contribution of IJOMEH publications to the world circulation of scientific information based on the citation analysis. The analysis, grounded on the SCOPUS database, assessed the frequency of citations in the years 1996-2005. Journals in which they have been cited were retrieved and their list is also included.
\end{abstract}

Key words:

Occupational medicine, Environmental health, Toxicology, Periodicals, Databses, SCOPUS

\section{INTRODUCTION}

The progress in the development of information technology (IT), observed in recent years, provides new perspectives for scientific journal editing. Besides traditional printed forms, a growing number of electronic publications are now on offer. Digitally recorded publications displayed on a computer screen have become more and more frequent source of information.

Electronic version of IJOMEH, introduced in 2006, provided the readers with new opportunities for accessing the Journal via the Internet services. This fact also proved to be a real inspiration to perform an analysis aimed at summing up citations (Cyt) of papers (Pub) published earlier. The analysis covered the years 1996-2005 and used the multidisciplinary SCOPUS database of the Elsevier B.V. The database, available since 2004, embraces numerous branches of extensive knowledge [1]. It contains 27 million records and 230 million references from over 14 thousand journals. About $60 \%$ of periodicals originate from other countries than the United States, so that European journals are also given an opportunity to be included in the circulation of information. The SCOPUS database facilitates the navigation around the world of scientific publications with abstracts being attached since 1966. An analysis of citations could have been made from 1996 [2].

\section{MATERIALS AND METHODS}

The SCOPUS database, available via the Internet in the Nofer Institute of Occupational Medicine, Łódź, was used in the analysis of citations. The retrieval results obtained from the database content as of March 3, 2006 were thoroughly analyzed. The analysis covered all papers published in 19962005 and documented in the database. Citations were traced following the references attached to each abstract. 


\section{RESULTS}

In 1996-2005, all 444 (100\%) articles, including editorials, original papers, review papers and bibliographic reviews, published in IJOMEH, were documented in the SCOPUS database (Table 1). The number of citations from retrieved articles accounted for 985, with mean rate (the number of citations per one publication calculated as the Cyt/Pub ratio) of 2.22. The 1998 publications were cited most frequently, mean rate of 4.88 (Fig. 1). This high rate was due to 35 citations of one article and over dozen citations of several other articles (Table 2, Fig. 2). The 1997 articles were also repeatedly cited with rate of 4.02 . It will be feasible to sum up citations of 2004-2005 only after a longer time interval in view of the publishing cycle, rate of information dissemination and time needed for data updating. The distribution of citations from a given annual volume in the years under study was also analyzed (Table 2). The obtained data show a diminishing time-lag between publication and citation of an article. From 2001, first citations have appeared already in the year, in which papers were published, and following the example of the 9/1996 volume, they are still cited after nine years (12 citations in 2005). The interest in a given article mostly arouses $2-6$ years after its publication. Over the recent years, a general increase in the number of citations has undoubtedly occurred due to easier and expanded access to databases and information services. However, the role of IT should not be overestimated as it is only an auxiliary tool in retrieval of a desired publication. As a matter of fact, the

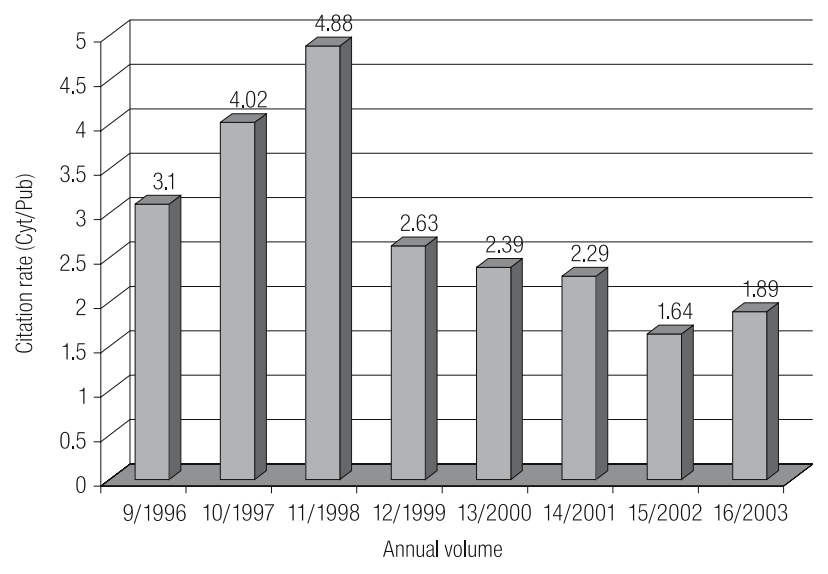

Fig. 1. The rate of IJOMEH citations, 1996-2003. subject itself and innovatory ideas presented in the papers are a decisive factor that evokes interest in it, and using various numerical indicators one should bear in mind that those are of only secondary importance [3].

It was also checked, which of IJOMEH articles were cited most frequently. The analysis of frequency of papers citations in the years under study is summarized in Table 3. The utmost interest was evoked by one paper published in 1998 expressed by 35 citations. This was followed by one of 1996 - 25 citations and one of 1999 - 19 citations. Papers cited more than 10 times are listed in Table 4.

Table 1. The documented 1996-2005 publications and the number of citations

\begin{tabular}{ccccc}
\hline \multicolumn{1}{c}{$\begin{array}{c}\text { No. of articles } \\
\text { in individual } \\
\text { issues of } \\
\text { IJOMEH }\end{array}$} & $\begin{array}{c}\text { No. of } \\
\text { documents in } \\
\text { the SCOPUS } \\
\text { database } \\
\text { (Pub) }\end{array}$ & $\begin{array}{c}\text { No. of } \\
\text { citations as of } \\
\text { March 3, 2006 } \\
\text { (Cyt) }\end{array}$ & $\begin{array}{c}\text { Citation rate } \\
\text { (Cyt/Pub) }\end{array}$ \\
\hline $9 / 1996$ & 41 & 41 & 127 & 3.10 \\
$10 / 1997$ & 45 & 45 & 181 & 4.02 \\
$11 / 1998$ & 33 & 33 & 161 & 4.88 \\
$12 / 1999$ & 38 & 38 & 100 & 2.63 \\
$13 / 2000$ & 36 & 36 & 86 & 2.39 \\
$14 / 2001$ & 56 & 56 & 128 & 2.29 \\
$15 / 2002$ & 50 & 50 & 82 & 1.64 \\
$16 / 2003$ & 44 & 44 & 83 & 1.89 \\
$17 / 2004$ & 59 & 59 & 35 & 0.59 \\
$18 / 2005$ & 42 & 42 & 2 & 0.05 \\
\hline Total & 444 & 444 & 985 & 2.22 \\
\hline
\end{tabular}

Table 2. Citations of articles from individual IJOMEH annual volumes, 1997-2006

\begin{tabular}{cccrrrrrrrrr}
\hline Vol. & 1997 & 1998 & 1999 & 2000 & 2001 & 2002 & 2003 & 2004 & 2005 & 2006 & Cyt. \\
\hline $9 / 1996$ & 5 & 9 & 15 & 17 & 20 & 22 & 15 & 12 & 12 & 0 & 127 \\
$10 / 1997$ & 0 & 3 & 11 & 31 & 29 & 26 & 27 & 25 & 27 & 2 & 181 \\
$11 / 1998$ & & 0 & 2 & 16 & 20 & 27 & 27 & 36 & 26 & 7 & 161 \\
$12 / 1999$ & & & 0 & 7 & 9 & 13 & 23 & 25 & 22 & 1 & 100 \\
$13 / 2000$ & & & & 0 & 8 & 13 & 23 & 18 & 20 & 4 & 86 \\
$14 / 2001$ & & & & & 2 & 17 & 25 & 41 & 34 & 9 & 128 \\
$15 / 2002$ & & & & & & 3 & 15 & 33 & 26 & 5 & 82 \\
$16 / 2003$ & & & & & & & 6 & 26 & 49 & 2 & 83 \\
$17 / 2004$ & & & & & & & & 4 & 28 & 3 & 35 \\
$18 / 2005$ & & & & & & & & & 2 & 0 & 2 \\
\hline Total & 5 & 12 & 28 & 71 & 88 & 121 & 161 & 220 & 246 & 33 & 985 \\
\hline
\end{tabular}


Table 3. Frequency of IJOMEH articles citations

\begin{tabular}{cccccccccccccccccccccccccc}
\hline \multirow{10}{*}{ Year } & \multicolumn{1}{c}{} & 0 & 1 & 2 & 3 & 4 & 5 & 6 & 7 & 8 & 9 & 10 & 11 & 12 & 13 & 14 & 15 & 16 & 17 & 18 & 19 & 25 & 35 & Publ. \\
\hline 1996 & 15 & 8 & 4 & 2 & 3 & 2 & 0 & 2 & 0 & 1 & 0 & 2 & 0 & 1 & 0 & 0 & 0 & 0 & 0 & 0 & 1 & 0 & 41 \\
1997 & 14 & 6 & 5 & 2 & 2 & 1 & 0 & 4 & 2 & 3 & 1 & 1 & 1 & 1 & 1 & 1 & 0 & 0 & 0 & 0 & 0 & 0 & 45 \\
1998 & 6 & 6 & 4 & 2 & 3 & 3 & 2 & 0 & 1 & 1 & 1 & 2 & 0 & 0 & 0 & 0 & 0 & 0 & 1 & 0 & 0 & 1 & 33 \\
1999 & 14 & 6 & 7 & 3 & 3 & 0 & 1 & 0 & 1 & 1 & 0 & 0 & 0 & 0 & 0 & 0 & 0 & 1 & 0 & 1 & 0 & 0 & 38 \\
2000 & 10 & 6 & 6 & 5 & 2 & 3 & 1 & 0 & 3 & 0 & 0 & 0 & 0 & 0 & 0 & 0 & 0 & 0 & 0 & 0 & 0 & 0 & 36 \\
2001 & 26 & 9 & 7 & 2 & 3 & 3 & 0 & 0 & 1 & 0 & 2 & 0 & 1 & 0 & 1 & 0 & 0 & 0 & 1 & 0 & 0 & 0 & 56 \\
2002 & 21 & 12 & 4 & 7 & 1 & 1 & 1 & 0 & 1 & 2 & 0 & 0 & 0 & 0 & 0 & 0 & 0 & 0 & 0 & 0 & 0 & 0 & 50 \\
2003 & 17 & 10 & 7 & 4 & 1 & 2 & 0 & 1 & 0 & 1 & 0 & 0 & 0 & 0 & 0 & 0 & 0 & 1 & 0 & 0 & 0 & 0 & 44 \\
2004 & 36 & 16 & 5 & 1 & 0 & 0 & 1 & 0 & 0 & 0 & 0 & 0 & 0 & 0 & 0 & 0 & 0 & 0 & 0 & 0 & 0 & 0 & 59 \\
2005 & 40 & 2 & 0 & 0 & 0 & 0 & 0 & 0 & 0 & 0 & 0 & 0 & 0 & 0 & 0 & 0 & 0 & 0 & 0 & 0 & 0 & 0 & 42 \\
\hline Total & 199 & 81 & 49 & 28 & 18 & 15 & 6 & 7 & 9 & 9 & 4 & 5 & 2 & 2 & 2 & 1 & 0 & 2 & 2 & 1 & 1 & 1 & 444 \\
\hline
\end{tabular}

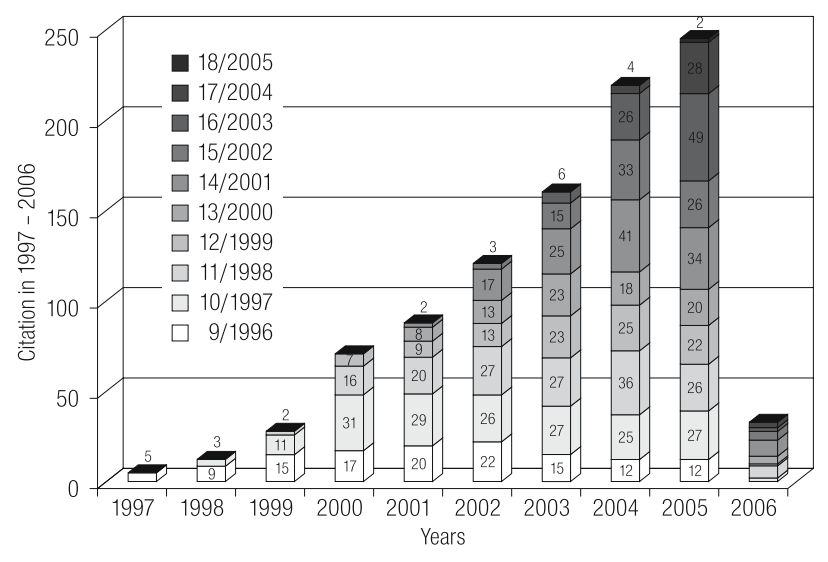

Fig. 2. Citations of articles from IJOMEH, 1997-2006.

\section{DISCUSSION AND CONCLUSIONS}

The presented analysis allowed for assessing the contribution of the international professional quarterly edited in Poland to the progress of world science. Owing to the access to the SCOPUS database that recorded all IJOMEH papers published in 1996-2005, it is possible to retrieve papers, which have proved to exert the strongest impact. Despite the fact that of 444 analyzed articles, 199 have not been cited (Table 3), it should be taken into account that publications most frequently cited are original papers addressing topics in line with the main current of the journal. The 444 documented papers also include editorials or bibliographic reviews, which are quite naturally not cited. The 26 papers, which have been most frequently cited concern such areas as toxicology, including harmful effects of chemical and physical factors on human health, environmental hazards, occupational exposure and related issues, or epidemiological studies. Their authors come from various research centers in different parts of the world (Poland, USA, Great Britain, Sweden, Netherlands, Germany, Italy). A large proportion of them has a small number of the author self-citations (of 382 citations, 53 self-citations). The majority of papers have been cited in foreign journals (of 382 citations, 354 were found in foreign journals). Table 5 gives the titles of journals, in which IJOMEH articles have been cited most frequently. These are major medical periodicals of the toxicological profile with granted impact factor (IF) [4].

As depicted by the analysis, the results of research studies published in IJOMEH are disseminated throughout the world via biomedical journals classified high in the ranking. The International Journal of Occupational Medicine and Environmental Health has not yet been granted IF, but since 2005 it has been indexed in the databases of BIOSIS PREVIEWS and BIOLOGICAL ABSTRACTS issued by the Institute for Scientific Information (ISI), at present known as Thomson Scientific, and thus it is now placed on the Master Journal List (the list of journals recorded in the ISI databases) [5].

The review of the most frequently cited articles shows a growing interest in topics discussed in IOMEH, especially after 2000. The list of journals, in which IJOMEH papers are cited confirms a significant share of works devoted to 
Table 4. List of IJOMEH papers most frequently cited

\begin{tabular}{|c|c|c|c|c|}
\hline No. & Publication & $\begin{array}{c}\text { Citations } \\
\text { (self-citations) }\end{array}$ & $\begin{array}{l}\text { In foreign } \\
\text { journals }\end{array}$ & $\begin{array}{c}\text { Year of citation } \\
\text { (number of citation) }\end{array}$ \\
\hline 1 & $\begin{array}{l}\text { Carpenter DO. Polychlorinated biphenyls and human health. Int J Occup } \\
\text { Med Environ Health 1998;11(4):291-303 }\end{array}$ & $35(8)$ & 34 & $\begin{array}{l}2006 \text { (5); } 2005 \text { (10); } 2004(9) ; 2003(2) ; \\
\text { 2002 (2); 2001(4); } 2000 \text { (3) }\end{array}$ \\
\hline 2 & $\begin{array}{l}\text { Parke DV, Sapota A. Chemical toxicity and reactive oxygen species. Int J } \\
\text { Occup Med Environ Health 1996;9(4):331-40 }\end{array}$ & $24(1)$ & 23 & $\begin{array}{l}2005(4) ; 2004(4) ; 2003(5) ; 2002(2) ; \\
2001(3) ; 2000(4) ; 1999(1) ; 1997(1)\end{array}$ \\
\hline 3 & $\begin{array}{l}\text { Prasher D, Sułkowski W. The role of otoacoustic emissions in screening } \\
\text { and evaluation of noise damage. Int J Occup Med Environ Health } \\
\text { 1999;12(2):183-92 }\end{array}$ & $19(1)$ & 17 & $\begin{array}{c}2005(6) ; 2004(5) ; 2003(3) ; 2002(3) ; \\
2001(2)\end{array}$ \\
\hline 4 & $\begin{array}{l}\text { Reszka E, Wąsowicz W. Significance of genetic polymorphisms in } \\
\text { glutathione S-transferase multigene family and lung cancer risk. Int J Occup } \\
\text { Med Environ Health 2001;14(2):99-113 }\end{array}$ & $18(0)$ & 18 & $\begin{array}{l}2004(1) ; 2004(6) ; 2003(7) ; 2002(3) ; \\
2001(1)\end{array}$ \\
\hline 5 & $\begin{array}{l}\text { Kieć-Świerczyńska M, Kręcisz B, Krysiak B, Kuchowicz E, Rydzynski } \\
\text { K. Occupational allergy to aldehydes in health care workers. Clinical } \\
\text { observations. Experiments. Int J Occup Med Environ Health } \\
\text { 1998;11(4):349-58 }\end{array}$ & $18(5)$ & 16 & $\begin{array}{l}2006(1) ; 2005(2) ; 2004(2) ; 2003(2) ; \\
\quad 2002(4) ; 2001(2) ; 2000(5)\end{array}$ \\
\hline 6 & $\begin{array}{l}\text { Jaga K, Dharmani C. Global surveillance of DDT and DDE levels in } \\
\text { human tissues. Int J Occup Med Environ Health 2003;16(1):7-20 }\end{array}$ & $17(0)$ & 17 & 2005 (11); 2004 (4); 2003 (2) \\
\hline 7 & $\begin{array}{l}\text { Persson B, Fredrikson M. Some risk factors for non-Hodgkin's lymphoma. } \\
\text { Int J Occup Med Environ Health 1999;12(2):135-42 }\end{array}$ & $17(0)$ & 17 & $\begin{array}{l}2006 \text { (1); } 2005 \text { (4); } 2004(4) ; 2003(2) ; \\
\quad 2002 \text { (1); } 2001 \text { (4); } 2000 \text { (1) }\end{array}$ \\
\hline 8 & $\begin{array}{l}\text { Skoczyńska A, Smolik R. The effect of combined exposure to lead and } \\
\text { cadmium on serum lipids and lipid peroxides level in rats. Int J Occup Med } \\
\text { Environ Health 1994;7(3):263-71 }\end{array}$ & $17(1)$ & 15 & $\begin{array}{l}2005(2) ; 2004(4) ; 2003(4) ; 2002(3) ; \\
2001(4)\end{array}$ \\
\hline 9 & $\begin{array}{l}\text { Wiśniewska-Knypl J.M, Wrońska-Nofer T. Biological markers of oxidative } \\
\text { stress induced by ethanol and iron overload in rat. Int J Occup Med } \\
\text { Environ Health 1994;7(4):355-63 }\end{array}$ & $16(1)$ & 12 & $\begin{array}{l}2006(1) ; 2005(3) ; 2004(1) ; 2003(5) ; \\
2002(1) ; 2000(1) ; 1997(2) ; 1996(1)\end{array}$ \\
\hline 10 & $\begin{array}{l}\text { Moszczyński P. Mercury compounds and the immune system: A review. Int } \\
\text { J Occup Med Environ Health 1997;10(3):247-58 }\end{array}$ & $15(0)$ & 15 & $\begin{array}{l}2006 \text { (1); } 2005 \text { (2); } 2004(1) ; 2003(3) ; \\
\quad 2002 \text { (2); } 2001(4) ; 2000(2)\end{array}$ \\
\hline 11 & $\begin{array}{l}\text { Karagas MR, Le CX, Morris S, Blum J, Lu X, Spate V, Carey M, } \\
\text { Stannard V, Klaue B, Tosteson TD. Markers of low level arsenic exposure } \\
\text { for evaluating human }\end{array}$ & $14(5)$ & 14 & $\begin{array}{l}2006(1) ; 2005(4) ; 2004(6) ; 2003(1) ; \\
2002(2)\end{array}$ \\
\hline
\end{tabular}
for evaluating human cancer risks in a US population. Int J Occup Med Environ Health 2001;14(2):171-5

12 De Zwart BCH, Broersen JPJ, Van der Beek AJ, Frings-Dresen MHW, Van Dijk FJH. Occupational classification according to work demands: An evaluation study. Int J Occup Med Environ Health 1997;10(3):283-95

13 Gralewicz S, Soćko R. Persisting behavioural and electroencephalographic effects of exposure to chlorphenvinphos, an organophosphorous pesticide, in laboratory animals. Int J Occup Med Environ Health 1997;10(4):375-94

14 Pepłońska B, Szeszenia-Dąbrowska N, Sobala W, Wilczyńska U. A mortality study of workers with reported chronic occupational carbon disulfide poisoning.Int J Occup Med Environ Health 1996;9(4):291-99

15 Muttray A, Wolters V, Mayer-Popken O, Schicketanz KH, Konietzko J. Effect of subacute occupational exposure to toluene on color vision. Int J Occup Med Environ Health 1996;8(4):339-45

16 Settimi L, Comba P, Bosia S, Ciapini C, Desideri E, Fedi A, Perazzo PL, Axelson O. Cancer risk among male farmers: A multi-site case-control study. Int J Occup Med Environ Health 2001;14(4):339-47

17 Wesołowski W, Gromiec JP. Occupational exposure in Polish paint and lacquer industry. Int J Occup Med Environ Health 1997;10(1):79-88 
18 Jędrychowski W, Flak E. Separate and combined effects of the outdoor and indoor air quality on chronic respiratory symptoms adjusted for allergy among preadolescent children. Int J Occup Med Environ Health 1998;11(1):19-35

19 Stetkiewicz J, Wrońska-Nofer T. Updating of hygiene standards for carbon disulfide based on health risk assessment. Int J Occup Med Environ Health 1998;11(2):129-43

20 Szadkowska-Stańczyk I, Boffetta P, Wilczyńska U, Szeszenia-Dąbrowska $\mathrm{N}$, Szymczak W. Cancer mortality among pulp and paper workers in Poland. A cohort study. Int J Occup Med Environ Health 1997;10(1):19-29

21 Persson B. Occupational exposure and malignant lymphoma. Int J Occup Med Environ Health 1996;9(4):309-21

22 Kłuciński P, Hrycek A, Stasiura-Zielińska H, Kossmann S, Tustanowski J, Friedek D, Kamińska-Kołodziej B. Humoral and cellular immunity rates in chemical plant workers employed in the production of liquid pesticides. Int J Occup Med Environ Health 1996;9(2):103-10

23 Sińczuk-Walczak H, Jakubowski M, Matczak W. Neurological and neurophysiological examinations of workers occupationally exposed to manganese. Int J Occup Med Environ Health 2001;14(4):329-37

24 Carpenter DO. Effects of metals on the nervous system of humans and animals. Int J Occup Med Environ Health 2001;14(3):209-18

25 Belkic K, Emdad R, Theorell T. Occupational profile and cardiac risk: Possible mechanisms and implications for professional drivers. Int J Occup Med Environ Health 1998;11(1):37-57

26 Dudek B, Merecz D. Impairment of psychological functions in children environmentally exposed to lead. Int J Occup Med Environ Health 1997;10(1):37-46

\begin{tabular}{|c|c|c|}
\hline $11(1)$ & 11 & $\begin{array}{l}2005 \text { (2); } 2004 \text { (3); } 2003 \text { (2); } 2002(2) ; \\
2001 \text { (1); } 2000 \text { (1) }\end{array}$ \\
\hline $11(1)$ & 11 & $\begin{array}{c}2006 \text { (1); } 2005 \text { (1); } 2004(4) ; 2003(2) ; \\
2002 \text { (2); } 2001(1)\end{array}$ \\
\hline $11(5)$ & 10 & $\begin{array}{c}2004 \text { (1); } 2002 \text { (2); } 2001 \text { (3); } 2000 \text { (2); } \\
1999 \text { (2); } 1998 \text { (1) }\end{array}$ \\
\hline $11(0)$ & 11 & $\begin{array}{l}2005 \text { (1); } 2004 \text { (2); } 2003 \text { (1); } 2002 \text { (2); } 2001 \\
\text { (1); } 2000 \text { (1); } 1999 \text { (2); } 1998 \text { (1) }\end{array}$ \\
\hline $11(2)$ & 10 & $\begin{array}{l}2005 \text { (1); } 2004 \text { (1); } 2002 \text { (1); } 2001(2) ; \\
2000 \text { (2); } 1999 \text { (3); } 1998 \text { (1) }\end{array}$ \\
\hline $10(1)$ & 9 & 2005 (5); 2004 (2); 2003 (3) \\
\hline $10(0)$ & 10 & $\begin{array}{c}2006(1) ; 2005(3) ; 2004(2) ; 2003(3) ; \\
2002(1)\end{array}$ \\
\hline $10(2)$ & 10 & $\begin{array}{c}2005 \text { (2); } 2004 \text { (3); } 2003 \text { (2); } 2002(1) ; \\
2001(2)\end{array}$ \\
\hline $10(0)$ & 10 & $\begin{array}{l}2005 \text { (1); } 2004 \text { (2); } 2002 \text { (2); } 2001 \text { (2); } \\
2000(3)\end{array}$ \\
\hline
\end{tabular}

Total $382(53) \quad 354$

Table 5. Journals, in which IJOMEH papers have been most frequently cited

\begin{tabular}{lc}
\hline \multicolumn{1}{c}{ Journal } & IF 2004 \\
\hline $\begin{array}{l}\text { International Journal of Occupational } \\
\text { and Environmental Medicine }\end{array}$ & 1.033 \\
Occupational and Environmental Medicine & 1.916 \\
Environmental Health Perspectives & 3.923 \\
Scandinavian Journal of Work, Environment and Health & 1.991 \\
NeuroToxicology & 2.500 \\
Toxicology & 2.691 \\
Journal of Toxicology and Environmental Health & 1.548 \\
Toxicology Letters & 2.571 \\
Environmental Research & 1.793 \\
Polish Journal of Environmental Studies & 0.366 \\
Journal of Occupational and Environmental Medicine & 1.784 \\
International Archives of Occupational Health & 1.292 \\
American Journal of Industrial Medicine & 1.617 \\
Cancer Causes and Control & 2.847 \\
Archives of Toxicology & 1.770 \\
\hline
\end{tabular}

occupational medicine, toxicology or environmental health in the world circulation of scientific information.

\section{REFERENCES}

1. Burnham JF. Scopus database: a review [cited 2006 March 27]. A Bimed Digit Libr 2006;3(1). Available from: http://www.biodigitlib.com/content/3/1/1.

2. Dess HM. Scopus [cited 2006 March 29]. Iss Sci Technol Librarianship 2006;45. Available from: http://www.istl.org/06-winter/databases4.html.

3. Monastersky R. The number that's devouring science. The impact factor, once a simple way to rank scientific journals, has become an unyielding yardstick for hiring, tenure, and grants [cited 2006 March 27]. The Chronicle of Higher Education. Section: Research \& Publishing 2005; 52(8): A12. Available from: http://chronicle.com/free/v52/i08/ 08a01201.htm.

4. Garfield E. The history and meaning of the journal impact factor. JAMA 2006; 295(1): 90-3.

5. Thomson Scientific. Master Journal List [cited 2006 March 23]. Available from: http://scientific.thomson.com/mjl/. 